\title{
UDK 528.481+551.242
}

\author{
V. PAVLYK ${ }^{1 *}$, A. KUTNYI ${ }^{1}$, O. KALNYK ${ }^{2}$ \\ ${ }^{1}$ Poltava Gravimetric Observatory of Subbotin Institute of Geophysics of NAS of Ukraine, 27/29, G. Myasoedova Str., \\ Poltava, Ukraine, 36004, e-mail: vgpavlyk@gmail.com, tel. 0991715137. \\ ${ }^{2}$ Poltava National Technical Yuri Kondratyuk University, 24, Pershotravnevyi Ave., Poltava, Ukraine, 36011, e-mail: \\ alex.kalnik@gmail.com.
}

https://doi.org/10.23939/jgd2019.02.016

\section{FEATURES OF THE INFLUENCE OF SEASONAL VARIATION OF SOIL MOISTURE ON VERTICAL MOVEMENTS OF THE EARTH'S SURFACE}

The purpose of the research is to establish experimentally the most favorable conditions for determining the vertical movements of the Earth's surface in terms of the minimal influence of variations of soil moisture on the results of observations. Geodetic monitoring of deformation processes at geodynamic testing grounds (GTG) occurs mainly without taking into account the influence of factors on the dynamics of the Earth's surface and benchmarks. To successfully separate tectonic or anthropogenic movements from all recorded motions of the Earth's surface, it is necessary to exclude their hydrometeorological component. One type of meteorological impact on the dynamics of the Earth's surface and benchmarks is the volumetric deformation of the swelling soils due to the variation of their moisture. They cause seasonal vertical movements, the magnitude of which depends on the physical and mineralogical properties of the soil, the characteristics of the environment, and the amplitude of annual fluctuations in temperature and moisture. The research methodology included the parallel observations at two points of vertical movements and moisture of the top one-meter layers of soil at GTS in Poltava for the period 2006 to 2015. The main result is the determination of a nonlinear nature of the effect of seasonal changes of soil moisture on the vertical displacement of the Earth's surface, depending on the absolute values of moisture. If soil moisture exceeds its maximum molecular moisture content (MMMC), then its variations do not affect the dynamics of the ground. This is explained by the different mechanism of vertical infiltration of water in the soil, depending on its water saturation. At high levels of soil moisture, further changes are caused mainly by capillary and gravitational forces that do not cause deformations and vertical movements of the Earth's surface. The scientific novelty of this research is to establish the important role of the MMMC of soil in the generation of vertical movements of the Earth's surface and benchmarks due to variations in its moisture. The practical significance of the work lies in the possibility of minimizing the influence of hydrometeorological factors on the results of high-precision observations of the dynamics of the Earth's surface. The results obtained can be used in the organization of high-precision observations of vertical movements on the GTG and their interpretation.

Key words: repeat leveling; seasonal vertical movements of the Earth's surface; soil moisture; benchmarks stability.

\section{Introduction}

The quantitative spatio-temporal characteristics of the deformation processes studied at the GTG represent the total impact of tectonic, human-made, and exogenous factors. For successful interpretation of the results of the observations, it is necessary to separate the individual components of the recorded movements of the Earth's surface.

Exogenous vertical movements of hydrometeorological origin can be caused by changes in atmospheric and hydrological loads on the surface of the Earth, volumetric deformations of the soil, which occur as a result of changes in its temperature and moisture. Using the models of the atmosphere and the distribution of water in the continental parts of the Earth, it is possible to calculate the load on the Earth's surface and obtain the corresponding fields of its displacement at a global and regional scale [Rabbel \& Zchau, 1985; Dam, et al., 2001; Clark, 2007].
Volumetric deformations of the upper layers of soil depend on the physical and mineralogical composition of the soil, the magnitude of variations of its temperature and moisture, terrain, features of biological processes of plant life, etc. [Rusanov, 1961; Pavlyk, et al., 1996; Pavlyk, 2010, 2011; Demoulin, 2004]. The physical and mineralogical composition of the soil determine the potential for vertical displacements of the Earth's surface, which are realized only in the presence of variations in hydrometeorological factors. As the meteorological parameters change with annual frequency, this component is dominant in the spectrum of vertical movements of the upper soil layers. Seasonal vertical oscillations of the bedrock and sandy soils are mainly caused by variations in temperature and do not exceed $1 \mathrm{~mm}$ [Dong, et al., 2002; Pavlyk, 2010]. Periodic deformations of soils, which include clay components, caused primarily by fluctuations in its moisture and be as much as tens of millimeters [Rusanov, 1961; Pavlyk et al., 1996, Vittuari, et al., 
2015]. The largest seasonal vertical displacements exceed 100 millimeters and occur on peat and marsh soils [Zurowski, 1971; Chimitdorzhiev et al., 2013]. Therefore, ignoring periodic displacements of the ground and benchmarks due to variations in soil moisture can lead to significant errors in determining the quantitative characteristics of tectonic or anthropogenic deformations.

Three basic methods are used to study vertical motions: repeat leveling, GPS observations and radar interferometry that allows monitoring with millimeter accuracy [Ferretti et al., 2009; Hooper, et al., 2012]. Successful interpretation of the observations of the dynamics of the Earth's surface requires the stability of the geodetic base to hydrometeorological effects or information about the magnitudes of their temporal changes. Geodetic benchmarks, GPS monuments, and checkpoints for differential radar interferometry often produce seasonal variations of their surrounding soils. [Nicolas et. al, 2006; Szczerbowski, 2009; Ji, \& Herring, 2012]. Based on the repeated determination of benchmark heights along a $40 \mathrm{~km}$ long profile in Western Australia, it has been shown that seasonal oscillation information for benchmarks is necessary to obtain reliable data on the velocity of vertical movements of the Earth's surface, especially in the case of a short interval between repeated leveling [Lyon, et al., 2018]. Only 40\% of the actual magnitude of the annual vertical oscillations obtained from continuous GPS observations can be explained by the influence of known factors such as ocean (tidal and non-tidal), atmospheric and hydrological loads, tidal pole motion [Dong et al., 2002]. Determination of the parameters of the seasonal component of the displacement of the Earth's surface by means of repeat leveling made it possible to explain the nature of vertical movements according to radar interferometric observations at the Ust-Selenga test area [Chimitdorzhiev et al., 2013]. The above examples show the importance of information on the seasonal movement of the upper soil layers in the study of the dynamics of the Earth's surface by geodetic methods.

Variations in the moisture of clay soils cause their volumetric deformation and vertical movement. Soil water can be bound by sorption forces and free under capillary and gravitational forces. Variations in the amount of bound water in the soil cause changes in the thickness of the water films around its solids. This causes changes in the volume of the soil and as a result its vertical movement. Only weakly bound water that moves in the soil from thicker to thinner films and displace its solids is involved in this process [Tsytovich, 1973]. Strongly bound (hygroscopic) water is a constant value for a particular type of soil, and as well as free water, that only fills its pores, is not capable of causing deformation. The ratio between bound and free water depends largely on the particle size of the soil. In coarse-grained soils most of the water is in the free state and in fine-grained soils in the bound one. Therefore, in sandy soils vertical movements due to changes in its moisture are practically absent, but in clay and loamy soil they reach considerable magnitudes. The maximum amount of bound water that the soil can accumulate is called its MMMC. Moistening the soil to the value of its MMMC occurs under the action of sorption forces. This process is accompanied by swelling of the soil and the vertical uplift of the Earth's surface. Further increase in soil moisture occurs mainly due to free water and should not cause deformation of the Earth's surface. The decrease of soil moisture to the MMMC value should also not be accompanied by its compression and sinking of the land surface [Feldman, 1988].

\section{Purpose}

The purpose of the research is, using the experimental data as the base, to establish the relationship between the magnitude of the vertical displacements of the ground surface and the moisture content of the topsoil at the GTG in Poltava. Confirmation of the fact that variations in soil moisture in excess of its MMMC have little effect on the vertical position of the Earth's surface will allow to determine the most favorable conditions and periods of geodetic observations. In this case, the vertical movement of the ground and benchmarks due to periodic swelling and compression of soils that respond to moisture change will be minimal.

\section{Methodology \\ Repeat leveling}

To achieve this goal, we used the results of observations at the GTG in Poltava, which was created to study the influence of local hydrometeorological factors on the dynamics of the ground surface. In this work we used the series of vertical movements of the upper one meter layer of soil according to the weekly observations by repeat leveling of the two surface benchmarks 5 and 7 for the period from June 2006 to December 2015. The benchmarks 5 and 7 are concrete monoliths with a height of $1 \mathrm{~m}$ and a diameter $0.18 \mathrm{~m}$, which are installed in the top one meter layer of soil. The benchmarks are located on plain terrain with grassy vegetation at the distance of $15 \mathrm{~m}$ from each other on medium loamy soils. The mechanical composition of the top one meter layer of soil near the benchmarks are as follows: the content of sand fractions (larger than $0.05 \mathrm{~mm})$ is $37 \%$, silt $(0.05-0.005 \mathrm{~mm})-45 \%$, clay (less than $0.005 \mathrm{~mm})-11 \%$, organic matter 7\% [Pavlyk, 2010].

Previously, we found that seasonal vertical movements of benchmarks at the GTG in Poltava are determined by instrumental methods to the depth of 4 $\mathrm{m}$ below the Earth's surface [Pavlyk, 1999]. Therefore, the vertical displacements of any of our benchmarks consist of the movement of its monolith in the upper one meter layer of soil $v_{0-1,0}$ and the 
integral movement of soil layers, which are located below its base to the depth of $4 \mathrm{~m} v_{1,0-4,0}$. The vertical movements of the benchmark 5 can be expressed as:

$$
v_{5}=v_{0-1,0}+v_{1,0-4,0} .
$$

The displacements of benchmarks 5 and 7 were determined relative to the base benchmark A15. This benchmark is a cylindrical concrete monolith with a height of $30 \mathrm{~cm}$. It is located in a well with a diameter of $18 \mathrm{~cm}$ and depth of $1.5 \mathrm{~m}$ from the surface of the land. Due to the well casing, the deformation of the soil layers above its foundation is not affected by the stability of this benchmark. Seasonal motions of the benchmark A15 consists of the movement of its monolith at the depth of 1.2-1.5 m from the Earth's surface $v_{1,2-1,5}$ and the integral movement of soil layers in the depth range from $1.5 \mathrm{~m}$ to $4.0 \mathrm{~m} v_{1,5-4,0}$ :

$$
v_{A 15}=v_{1,2-1,5}+v_{1,5-4,0} .
$$

The vertical movement of the soil layer below the concrete monolith of the benchmark $5 v_{1,0-4,0}$ can be divided into three separate components:

$$
v_{1,0-4,0}=v_{1,0-1,2}+v_{1,2-1,5}+v_{1,5-4,0} .
$$

Seasonal vertical motion of the benchmark 5 relative to the benchmark A15 $v_{A 15 ; 5}$ can be obtained as the difference of equations (2) and (1) taking into account the expression (3):

$$
v_{A 15 ; 5}=v_{A 15}-v_{5} \approx-v_{1,0-1,2}-v_{0-1,0} .
$$

The movement of the benchmark 7 will be similar to equation (4).

Thus, if the bottom of the tested benchmark and the top of the original one coincide, then the stability of the tested benchmark is not affected by the deformation of the soil layers below. This statement is valid only if both benchmarks are placed on a site with the same physical soil properties, terrain, climatic conditions, and other factors that cause seasonal vertical movements of soil layers at different depths. Benchmarks 5, 7, and A15 satisfy these conditions.

At the GTG in Poltava it was not possible to find such a base benchmark that would allow to completely exclude the dynamics of all soil layers below the investigated ones. However, according to our experimental data, the seasonal vertical movements of the soil layer 1.0-1.2 $\mathrm{m}$ does not exceed $5-7 \%$ compared to the top one meter layer $v_{0-1,0}$. This is confirmed by fig. 1 which shows the vertical movements of soil layers $0-0.9 \mathrm{~m}$ and 0.9-1.2 $\mathrm{m}$ from the surface of the ground, which were obtained at the GTG in Poltava in 2017-2018 near benchmarks 5 and 7 .

Therefore, in our studies, we neglect the vertical seasonal movements of the soil layer at a depth of 1.0$1.2 \mathrm{~m} v_{1,0-1,2}$, which are much smaller than the top one meter layer.

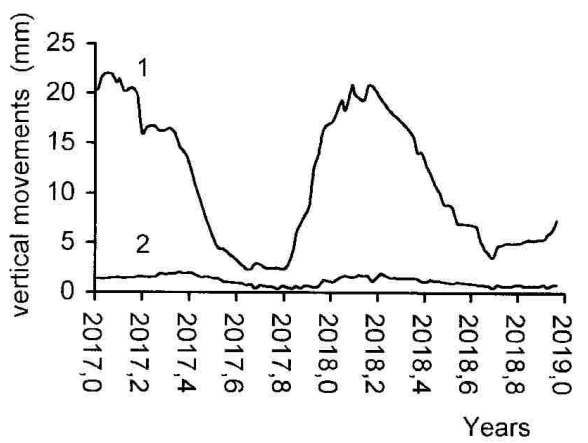

Fig. 1. Vertical movements at GTG in Poltava 2017 - 2018:

1 - soil layer 0-0.9 m; 2 - soil layer 0.9-1.2 m.

\section{Soil moisture monitoring}

Parallel to the geodetic observations at the GTG, the soil moisture was determined by the absolute gravimetric method [Grushka, 2005] to the depth of 1 $\mathrm{m}$ every $0.1 \mathrm{~m}$ near benchmarks 5 and 7 . This method is quite time-consuming, but is characterized by high accuracy. Moisture is determined as a percentage of the weight of water to the mass of dry soil. In winter, when the soil was frozen, the moisture was not determined. Monitoring of temporal changes in soil moisture by this method involves taking soil samples each time elsewhere. According to the results of our research, even at points that are only one meter apart, the moisture can differ by $3-4 \%$, which is much greater than its accuracy. This indicates a high degree of locality of this hydrological parameter. The relative accuracy of soil moisture determination at GPG in Poltava is 3-4 times lower than the accuracy of the vertical displacements of the Earth's surface according to the observations of the benchmarks. Therefore, to reduce the dispersion of individual moisture values, we have smoothed the original data by averaging three time-related values of this parameter.

\section{Results}

Variations in the moisture of individual soil layers may differently affect the integral vertical component of the dynamics of the Earth's surface, which is obtained on the basis of the observations of benchmarks 5 and 7. Therefore, to determine those soil layers whose deformations have a greater influence on the displacement of the Earth's surface, correlation coefficients were obtained between the 
relative vertical motions of each of the benchmarks on the one side and the moisture of the soil layers $0.1 \mathrm{~m}$ thick to a depth of $1 \mathrm{~m}$ on the other side. The calculated correlation coefficients are shown in Fig. 2.

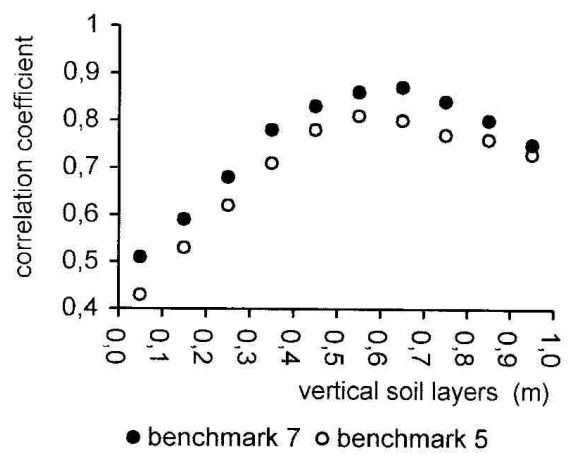

Fig. 2. Dependence of the correlation coefficients between the vertical movements at benchmarks 5 and 7 and the moisture of the soil layers with thickness $0.1 \mathrm{~m}$ in the depth range $0-1.0 \mathrm{~m}$ for the period 2006-2015.
According to Fig. 2 it can be concluded that the vertical motions of the surface benchmarks are caused to a greater extent by changes in the moisture in the soil layer of $0.4-0.8 \mathrm{~m}$. The reliability of the empirical correlation coefficients obtained [Smirnov \& Dunin-Barkovsky, 1965] is extremely high, since the mean square deviation of each is in the range 0.02 - 0.04. It is also interesting to note that the influence of moisture variations on the displacement of the benchmark 7 is systematically greater than for the benchmark 5 . This feature can be explained by the fact that the benchmark 7 is located in an open area, and 5 one near trees. Therefore, soil moisture near benchmark 5 due to increased transpiration should be higher than at benchmark 7 , which is reflected in the distribution of the obtained values of correlation coefficients.

Fig. 3 shows the vertical movements of the upper one meter layer of the Earth's surface according to repeated ten year observations of the benchmarks 5 and 7 and the corresponding moisture content of the soil layer at the depth of $0.4-0.8 \mathrm{~m}$.
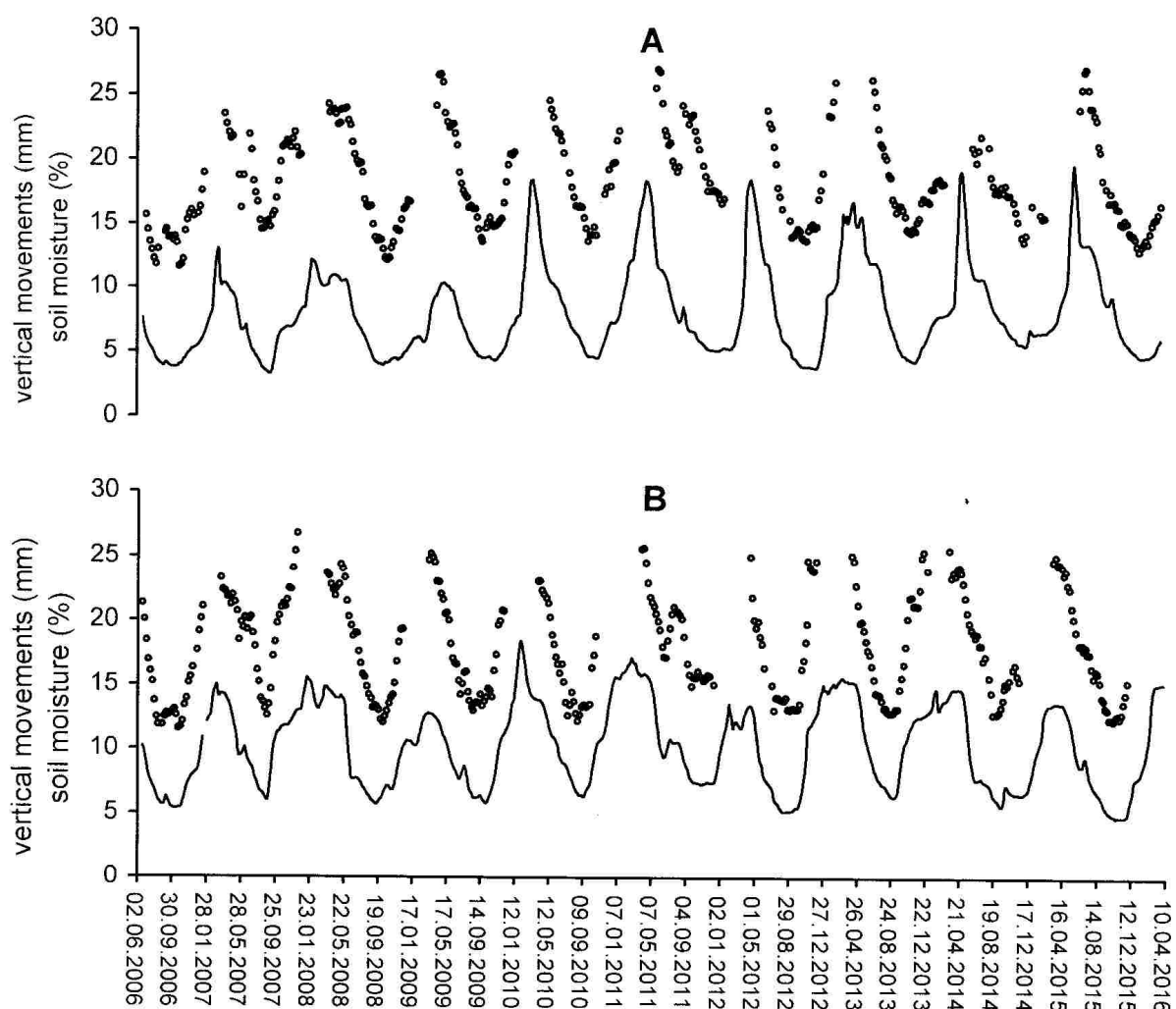

- vertical movements of the top 1-meter layer of soil
- soil moisture at the depth of $0,4-0,8 \mathrm{~m}$

Date

Fig. 3. Vertical movements of the top one-meter layer of soil in $\mathrm{mm}$ and its moisture at the depth of $0.4-0.8 \mathrm{~m}$ in \% at the GTG in Poltava for 2006-2015:

A - according to the observation of the benchmark 5, B - according to the observations of the benchmark 7 . 
To ensure the homogeneity of the output, the series of vertical displacements of the benchmarks are smoothed similarly to the soil moisture arrays. The mean square error of one value of vertical motions in Fig. 3 does not exceed $0.1 \mathrm{~mm}$.

The empirical correlation coefficients of the investigated time series of vertical motions and soil moisture are extremely high ( 0.93 for benchmark 7 and 0.88 for benchmark 5 for arrays longer than 350 values). This fact confirms the main role of variation of soil moisture in the generation of seasonal fluctuations of the Earth's surface at GTG in Poltava.

To study the dependence of the influence of moisture changes on the vertical displacement of the upper layer of the Earth's surface on the absolute value of soil moisture, the coefficient $k_{\mathrm{i}}$ was calculated. It is equal to the ratio of the change in the vertical position of the topsoil $\Delta h_{\mathrm{i}}$ to the change of its moisture $\Delta W_{\mathrm{i}}$ at the same time interval $\Delta t_{\mathrm{i}}$ :

$$
k_{i}=\frac{\Delta h_{i}}{\Delta W_{i}}
$$

The time interval $\Delta t_{\mathrm{i}}$ was chosen as small as possible. The magnitude of $\Delta W_{\mathrm{i}}$ is determined with less accuracy than $\Delta h_{\mathrm{i}}$. Therefore, it is subject to additional conditions. Changes in moisture in the determination of each individual value of $\Delta W_{\mathrm{i}}$ should exceed $2 \%$, so as not to doubt their real existence. The average value of $\Delta W_{\mathrm{i}}$ is $2.8 \%$. A total of $150 k_{\mathrm{i}}$ coefficient values were obtained during the whole observation period. The following is the grouping of the obtained coefficients according to the average absolute value of soil moisture. The average values of soil moisture are divided into six intervals: less than $15 \%, 15-17 \%, 17-19 \%, 19-21 \%, 21-23 \%$ and more than $23 \%$.

Fig. 4 shows the dependence of the coefficient $k$ (its dimension is $\mathrm{mm}$ of vertical displacement to $\%$ of soil moisture) on the absolute value of soil moisture in percent at benchmarks 5 and 7 .

According to Fig. 4, the effect of soil moisture on the studied parameter $k$ near benchmarks 5 and 7 differs little from each other. Existing differences can be explained by the high locality of soil moisture, which we noted above. If the soil moisture is more than $22 \%$, its effect on the vertical movement of the Earth's surface decreases considerably. If the soil moisture reaches $24 \%$ or more, its variations practically do not affect the altitude position of the Earth's surface. This means that at the GTG in Poltava the soil MMMC is about $24 \%$ and further increase of its moisture is mainly caused by capillary and gravitational forces that do not cause deformation of the land surface.

Fig. 5 and 6 show the absence of response of the Earth's surface to variations in soil moisture, if it exceeds its MMMC.

Considerable changes in soil moisture, which occurred in April 2013 near the benchmark 5 (Fig. 5), as well as from the end of March to the end of May
2008 near the benchmark 7 (Fig. 6) did not cause the corresponding vertical movements of the Earth's surface. Thus, the period of time when soil moisture exceeds its MMMC can be considered as the most favorable period for performing high-precision observations of the vertical component of the dynamics of the Earth's surface. At this time, the vertical position of the land surface is practically unchanged, despite considerable variations in soil moisture.

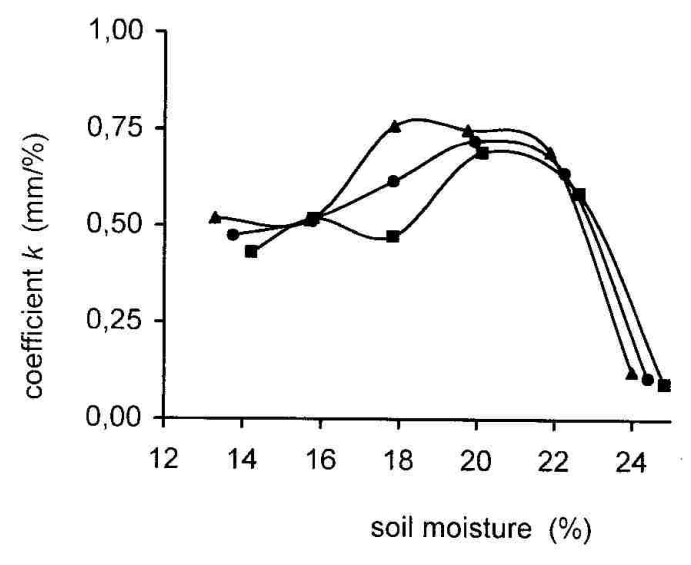

$\rightarrow$ benchmark $7 \rightarrow$ benchark $5 \multimap$ average

Fig. 4. Effect of absolute soil moisture on the value of the coefficient $k$ at benchmarks 5 and 7 .

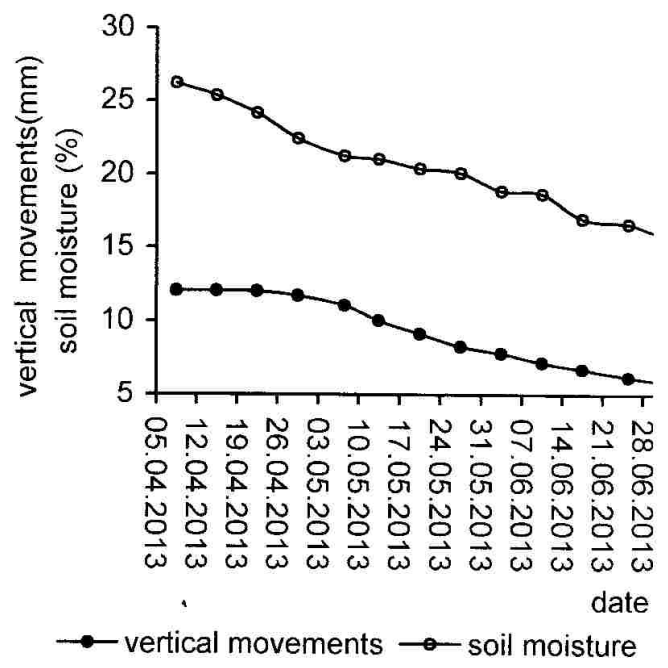

Fig. 5. Influence of variations in soil moisture near its MMMC on vertical movement at benchmark 5 .

In Fig. 7 and 8 the solid lines show the length of the favorable period for observations of vertical movements at benchmarks 5 and 7 for the period 2007-2015. The solid lines in show the length of the 
favorable period for the observation of vertical movements at benchmarks 5 and 7 for the same period.

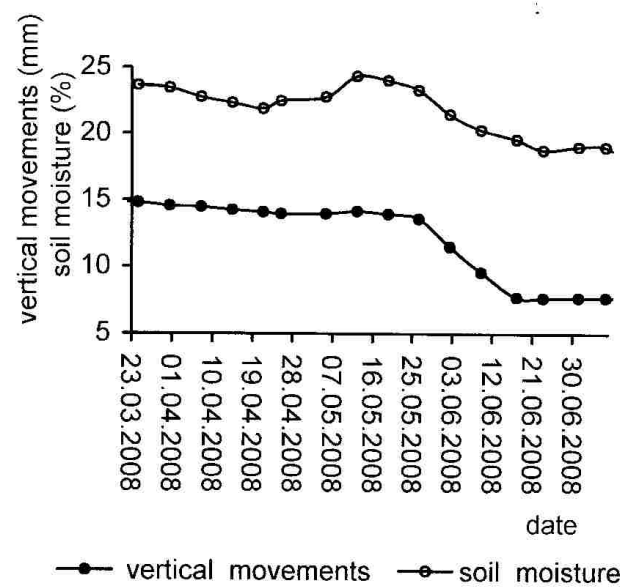

Fig. 6. Influence of variations in soil moisture near its MMMC on vertical movement at benchmark 7 .

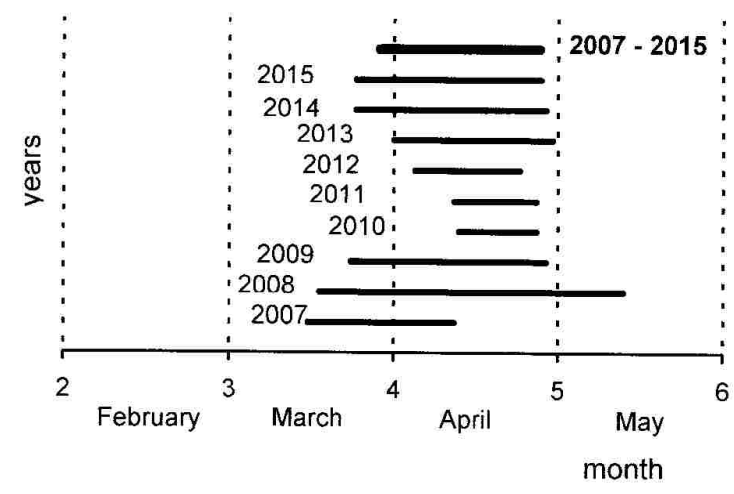

Fig. 7. Duration of favorable period for observation of the vertical movements at benchmark 5 2007-2015.

According to Fig. 7 and 8 the period of minimal influence of seasonal changes of soil moisture on the stability of the Earth's surface always occurs in the spring and can last from half of one month to two months. After the snow melts and the soil thaws, the moisture of its upper layers always exceeds its MMMC. In the open area (benchmark 7), the length of this period is longer than near trees (benchmark 5). This is explained by the fact that trees are an additional source of moisture reduction, especially in the spring, so the soil moisture near the benchmark 5 sooner becomes less than its MMMC. According to long-term observations, April is the most favorable for the geodetic observations of the vertical dynamics. Depending on the location of the site and the climatic features of a particular year, the period when the moisture of the topsoil exceeds the value of its MMMC may begin in late February and last until mid-May. In the case of heavy rainfall in autumn, a period of steady vertical position may occur at the end of the year before the soil freezes. The duration of this period rarely exceeds half a month and it does not happen every year.

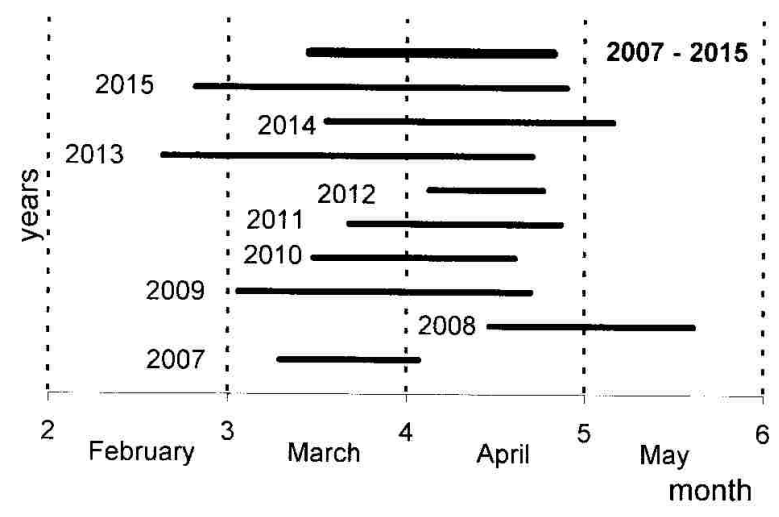

Fig. 8. Duration of favorable period for observation of the vertical movements at benchmark 7 2007-2015.

\section{Scientific novelty and practical significance}

On the basis of the experimental data, the important role of the MMMC soil in the generation of vertical displacements of hydrometeorological origin in the swelling soils is shown. If the soil moisture exceeds the value of its MMMC, then its subsequent changes do not cause deformation of the Earth's surface. This is due to a change in the nature of the movement of water in the soil and its state (free or bound) depending on the amount of moisture.

Determination of the numerical characteristics of the vertical dynamics of during the periods when the soil moisture exceeds its MMMC will minimize the influence of external hydrometeorological factors on the results of observations. At this time, the land and the benchmarks, which are set in the upper soil layers, do not respond to variations in moisture. The established regularity should be used in the organization of high-precision geodetic observations at the GTG and their interpretation.

\section{Conclusions}

1. On the basis of ten-year observations (2006 2015) at the GTG in Poltava the nonlinear nature of the influence of variations of soil moisture on the vertical displacement of the Earth's surface was revealed. If the absolute value of soil moisture exceeds its MMMC, then its subsequent changes have little effect on the vertical movement of the Earth's surface. This is explained by the differences in the mechanism of vertical infiltration of water into the 
soil, depending on its water saturation. If the moisture exceeds the value of the soil MMMC, its movement occurs mainly due to capillary forces and gravity, which do not affect deformation.

2. The value of the soil MMMC depends strongly on its physical properties. At the GTG, which is located on medium loamy soils, the index of moisture content is equal to $24 \%$. For finer dispersed soils that prevail in the south and east of Ukraine [Atlas ..., 1975, p. 116-117], the soil MMMC will be higher than in Poltava. For loamy soils of coarse structure, the value of their parameter will be smaller compared to the soils of our GTG.

3. The magnitude of the soil MMMC allows to establish optimal time periods for performing repeated geodetic observations on the vertical component of the dynamics of the Earth's surface in terms of minimizing the impact of soil moisture variations. For GTG in Poltava the average duration of this period is more than (one month the end of March and almost all of April). Depending on the climatic characteristics of a particular year, this period may be shorter or longer. With increasing magnitude of the soil MMMC, the period of stable altitude of the Earth's surface will decrease. A decrease in the magnitude of the soil MMMC will lead to an increase in the period favorable for geodetic observations. A decrease in the magnitude of the soil MMMC will increase the length of the favorable period for performing high-precision geodetic observations.

\section{REFERENCES}

Atlas of natural conditions and natural resources of the Ukrainian SSR. (1979). Moscow: GUGK (in Russian).

Chimitdorzhiev, T. N., Dagurov, P. N., Zakharov, A. I., Tatkov, G. I., Bykov, M. E., Dmitriev, A. V., Baldanov, N. D., Muhorin, E. A., \& Milheev, E. U. (2013). Estimation of seasonal deformations of marshy soil by radar interferometry and geodetic leveling techniques. Cryosphere of the Earth, XVII (1), 80-87 (in Russian).

Clarke, P. J., Lavallée, D. A., Blewitt, G., \& Dam, T. V. (2007). Basis functions for the consistent and accurate representation of surface mass loading. Geophysical Journal International, 171(1), 1-10. doi: 10.1111/j.1365246x.2007.03493.x.

Dam, T. V., Wahr, J., Milly, P. C. D., Shmakin, A. B., Blewitt, G., Lavallée, D., \& Larson, K. M. (2001). Crustal displacements due to continental water loading. Geophysical Research Letters, 28(4), 651-654. doi: 10.1029/2000gl012120.

Demoulin, A. (2004). Reconciling geodetic and geological rates of vertical crustal motion in intraplate regions. Earth and Planetary Science Letters, 221(1-4), 91-101. doi: 10.1016/s0012$821 \times(04) 00110-4$.

Dong, D., Fang, P., Bock, Y., Cheng, M. K., \& Miyazaki, S. I. (2002). Anatomy of apparent seasonal variations from GPS-derived site position time series. Journal of Geophysical Research: Solid Earth, 107(B4), ETG-9. doi: 10.1029/2001JB000573

Feldman, G. M. (1988) The movement of moisture in thawed and freezing soils. Novosibirsk: Science (in Russian).

Ferretti, A., Savio, G., Barzaghi, R., Borghi, A., Musazzi, S., Novali, F., ... \& Rocca, F. (2007). Submillimeter accuracy of InSAR time series: Experimental validation. IEEE Transactions on Geoscience and Remote Sensing, 45(5), 11421153. doi: 10.1109/TGRS.2007.894440

Grushka, I. G. (2005) Methods and means of measuring the moisture of materials and mediums. Scientific Works of UkrNDHMI, 254, 169-187 (in Ukrainian).

Hooper, A., Bekaert, D., Spaans, K., \& Arıkan, M. (2012). Recent advances in SAR interferometry time series analysis for measuring crustal deformation. Tectonophysics, 514, 1-13. doi: 10.1016/j.tecto.2011.10.013

Ji, K. H., \& Herring, T. A. (2012). Correlation between changes in groundwater levels and surface deformation from GPS measurements in the San Gabriel Valley, California. Geophysical Research Letters, 39(1). doi: 10.1029/2011GL050195

Lyon, T. J., Filmer, M. S., \& Featherstone, W. E. (2018). On the Use of Repeat Leveling for the Determination of Vertical Land Motion: Artifacts, Aliasing, and Extrapolation Errors. Journal of Geophysical Research: Solid Earth, 123(8), 70217039. doi: 10.1029/2018JB015705

Nicolas, J., Nocquet, J.-M., Camp, M. V., Dam, T. V., Boy, J.-P., Hinderer, J., ... Amalvict, M. (2006). Seasonal effect on vertical positioning by Satellite Laser Ranging and Global Positioning System and on absolute gravity at the OCA geodetic station, Grasse, France. Geophysical Journal International, 167(3), 1127-1137. doi: 10.1111/j.1365-246x.2006.03205.x

Pavlyk, V. G., Kutniy, A. M., Kryptova, V. V., \& Tyshchuk, M. F. (1996) Influence of soil moisture on seasonal vertical deformations of the Earth's surface. Geodesy, cartography and aerial photography, 57, 55-64 (in Ukrainian).

Pavlyk, V. G. (1999) Investigation of seasonal hydrothermal deformations of the Earth's surface at different depths. Geodesy, cartography and aerial photography, 59,19-23 (in Ukrainian).

Pavlyk, V. G. (2010) Seasonal hydrothermal vertical motions of the Earth's surface under conditions of different granulometric composition of soils. Geodynamics, 1 (9), 22-27 (in Ukrainian).

Pavlyk, V. G. (2011) Influence of atmospheric precipitation on vertical movements of Earth's surface in geodynamic micropolygon in Poltava. Geodynamics, 1 (10), 31-37 (in Ukrainian). 
Rabbel, W., \& Zchau, J. (1985) Static deformations and gravity changes at the Earth's surface due to atmospheric loading. Journal of Geophysics, 56(2), 81-99.

Rusanov, B. S. (1961) Hydrothermal motions of the Earth's surface. Moscow: USSR Academy of Sciences (in Russian).

Smirnov, N. I., \& Dunin-Barkovsky, I. V. (1965) The course of probability theory and mathematical statistics. Moscow: Higher school (in Russian).

Szczerbowski, Z. (2009) Toward the reliability of geodetic surveys in study of geodynamics - a problem of influence of seasonal variations. Acta
Geodynamica Et Geomaterialia, Vol.6, No.3 (155), 253-263.

Tsytovich N. A. (1973) Mechanics of soils. Moscow: Higher school (in Russian).

Vittuari, L., Gottardi, G., \& Tini, M. A. (2015). Monumentations of control points for the measurement of soil vertical movements and their interactions with ground water contents. Geomatics, Natural Hazards and Risk, 6(5-7), 439-453. doi: 10.1080/19475705.2013.873084

Zurowski, A. (1971) Remarks on the stability of some benchmarks in Zulawy Wislanych. Geodetic Review, 43(2), 507-509 (in Polish).

\section{В. Г. ПАВЛИК ${ }^{1 *}$, А. М. КУТНИЙ ${ }^{1}$, О. П. КАЛЬНИК ${ }^{2}$}

${ }^{1}$ Полтавська гравіметрична обсерваторія Інституту геофізики ім. С. І. Субботіна НАН України, вул. Г. Мясоєдова, 27/29, Полтава, 36011, Україна, ел. пошта: vgpavlyk@gmail.com, тел.0991715137.

${ }^{2}$ Полтавський національний технічний університет імені Юрія Кондратюка, просп. Першотравневий, 24 , Полтава, 36011, Україна, ел. пошта: alex.kalnik@gmail.com.

\section{ОСОБЛИВОСТІ ВПЛИВУ СЕЗОННИХ ВАРІАЦЙ ВОЛОГИ ГРУНТУ НА ВЕРТИКАЛЬНІ РУХИ ЗЕМНОÏ ПОВЕРХНІ}

Метою досліджень $є$ встановлення експериментальним шляхом найсприятливіших умов визначення вертикальних рухів земної поверхні з точки зору мінімального впливу варіацій вологи грунту на результати спостережень. Геодезичний моніторинг деформаційних процесів на геодинамічних полігонах (ГП) відбувається переважно без урахування впливу екзогенних чинників метеорологічного походження на динаміку земної поверхні та реперів. Для успішного виділення тектонічних чи техногенних рухів 3 усього спектру зареєстрованих переміщень земної поверхні потрібно вилучити їх гідрометеорологічну складову. Одним із видів метеорологічного впливу на динаміку земної поверхні та реперів $\epsilon$ об'ємні деформації набрякаючих грунтів внаслідок варіації їх вологи. Вони зумовлюють сезонні вертикальні рухи, величина яких залежить від фізичних та мінералогічних властивостей грунту, особливостей навколишнього середовища та амплітуди річних коливань температури і вологи. Методика досліджень передбачала паралельні спостереження у двох пунктах за вертикальними рухами і вологістю верхнього однометрового шару грунту на ГП у Полтаві за період 2006-2015 рр. Основним результатом роботи $\epsilon$ встановлення нелінійного характеру дії сезонних змін вологи грунту на вертикальні переміщення земної поверхні в залежності від абсолютного значення вологості. Якщо вологість грунту перевищує його максимальну молекулярну вологомісткість (ММВ), то її варіації не впливають на динаміку землі. Це пояснюється різним механізмом вертикальної інфільтрації води в грунті в залежності від його водонасиченості. При значній вологості грунту її подальші зміни зумовлені переважно капілярними та гравітаційними силами, які не викликають деформацій і вертикальних переміщень земної поверхні. Науковою новизною досліджень $є$ встановлення важливої ролі ММВ грунту в генерації вертикальних рухів земної поверхні та реперів внаслідок варіацій вологи. Практична значущість роботи полягає у можливості мінімізації впливу гідрометеорологічних чинників на результати високоточних спостережень за динамікою земної поверхні. Отримані результати можна використовувати для організації високоточних спостережень за вертикальними рухами на ГП та їх інтерпретації.

Ключові слова: повторне нівелювання; сезонні вертикальні рухи земної поверхні; вологість грунту; стійкість реперів.

Received 29.08.2019 